\title{
Evaluation of Rotational Biopesticide Programs for Disease Management in Organic Cucurbit Production
}

Sasha C. Marine, Mason J. Newark, and Robert C. Korir, Department of Plant Science and Landscape Architecture, University of Maryland, Lower Eastern Shore Research and Education Center, Salisbury 21801; and Kathryne L. Everts, Department of Plant Science and Landscape Architecture, University of Maryland, Lower Eastern Shore Research and Education Center, Salisbury 21801, and University of Delaware, Carvel Research and Education Center, Georgetown 19947

\begin{abstract}
Marine, S. C., Newark, M. J., Korir, R. C., and Everts, K. L. 2016. Evaluation of rotational biopesticide programs for disease management in organic cucurbit production. Plant Dis. 100:2226-2233.

Downy mildew (Pseudoperonospora cubensis) and powdery mildew (Podosphaera xanthii) are two of the most economically important and widespread cucurbit diseases. Disease management relies primarily on fungicide use, but frequent fungicide applications can lead to the development of resistant pathogen populations. In addition, more vegetables are being produced with organic practices, which prohibit the use of many fungicides. Incorporating biorational products into a disease management program may help mitigate the risk of fungicide resistance development while being compatible with organic production. Field trials were conducted for two years on organically managed land in Maryland with cucumber, muskmelon, pumpkin, and butternut squash to evaluate

the efficacy of four biorational products (i.e., Actinovate AG, OxiDate, Regalia, and Serenade Soil) when applied in a rotational program with copper against foliar cucurbit diseases. Generally, all biorational treatments resulted in significantly lower downy and powdery mildew severity compared with the nontreated plants, but the level of disease management was not significantly different than that provided by copper alone. However, Actinovate AG, OxiDate, and Serenade Soil each improved disease management on at least one crop, as compared with copper alone. Rotational programs with biopesticides are a viable disease management option for organic production of field-grown cucurbits in Maryland.
\end{abstract}

The Cucurbitaceae, or cucurbit family, is a diverse group of important cultivated plant species that includes cucumber (Cucumis sativus L.), muskmelon (Cucumis melo L.), pumpkin (Cucurbita pepo L.), squash (Cucurbita moschata Duch. and Cucurbita maxima Duch.), and watermelon (Citrullus lanatus [Thunb.] Matsum \& Nakai) (Pérez-García et al. 2009). In the United States, cucurbits have an annual value of approximately $\$ 1.43$ billion (Cantliffe et al. 2007), with more than 2,700 hectares (ha) of production in Maryland (United States Department of Agriculture 2014). Organic farming is one of the fastest growing agricultural segments, in which open-field vegetable production has increased 26\% since 2008 (United States Department of Agriculture 2015). Downy mildew (caused by Pseudoperonospora cubensis [Berk. \& M.A. Curtis] Rostovzev) and powdery mildew (caused by Podosphaera xanthii [Castag.] Braun $\&$ Shish. [syn. Sphaerotheca fuliginea (Schlechtend.:Fr.) Pollacci]) are two of the most economically important and widespread foliar cucurbit diseases (Lebeda and Cohen 2011; McGrath and Thomas 1996). Disease outbreaks occur annually in open-field production in Maryland. Heavily infected cucurbit crops exhibit premature defoliation, reduced yield, and decreased fruit quality, due to sunscald

Current address for S. C. Marine: Department of Plant Pathology, Physiology and Weed Science, Virginia Tech, Blacksburg 24061

Current address for M. J. Newark: Department of Plant Pathology, University of Florida, Gainesville 32611

Corresponding author: K. L. Everts; E-mail: keverts@umd.edu

Mention of trade names or commercial products in this publication is solely for the purpose of providing scientific information and does not imply recommendation or endorsement by University of Maryland.

Accepted for publication 21 May 2016.

http://dx.doi.org/10.1094/PDIS-02-16-0252-RE

(C) 2016 The American Phytopathological Society and reduced sugar levels (McGrath and Thomas 1996; Thomas 1996).

Both Pseudoperonospora cubensis and Podosphaera xanthii are obligate biotrophs, requiring living host tissue to survive and reproduce. Pseudoperonospora cubensis overwinters in geographic areas that do not experience a hard frost, so disease occurrence in Maryland and other northern states depends on the annual introduction of inoculum from the south via spring wind currents (Ojiambo and Holmes 2011) or via infected seed (Cohen et al. 2014). Pseudoperonospora cubensis isolates also exhibit a specific host range and, to date, five pathotypes have been described in the United States (Thomas et al. 1987). Cucumber, for example, is susceptible to all five Pseudoperonospora cubensis pathotypes, while pumpkin is susceptible to only one pathotype that tends to be more prevalent later in the growing season. In contrast to the downy mildew pathogen, Podosphaera xanthii is a ubiquitous species with a broad host range (Pérez-García et al. 2009) that may survive in fields as chasmothecia. These overwintering structures have been documented on cucurbit foliage in Indiana (Latin 1993), Michigan (McGrath et al. 1996), New York (McGrath 1991), and North Carolina (Grand 1987). However, chasmothecia occurrence is sporadic and has not been documented for Maryland.

Management of downy and powdery mildews relies primarily on the use of resistant cultivars or repeated application of synthetic fungicides. Unfortunately, commercially acceptable resistant cultivars are not readily available for all cucurbit crops (Lebeda and Cohen 2011) and a highly aggressive race of Pseudoperonospora cubensis recently overcame the durable source of downy mildew resistance in cucumber (derived from PI 197087) in the United States (Criswell et al. 2010). Fungicides are, therefore, an important disease management tool, with approximately $77 \%$ of United States cucumber acreage and $81 \%$ of United States watermelon acreage receiving annual treatments (Gianessi and Reigner 2006). However, frequent fungicide applications can lead to the development of resistant pathogen populations, especially when products containing active ingredients with the same mode of action are applied in succession. In the United States, resistance to benomyl, triadimefon, azoxystrobin, and trifloxystrobin has been reported in Podosphaera xanthii populations 
(McGrath 2001; McGrath and Shishkoff 2003). Previous studies have also documented resistance to metalaxyl, pyraclostrobin, and dimethomorph within United States Pseudoperonospora cubensis populations (Lebeda and Cohen 2011). Organic agriculture does not allow the use of these or other synthetic fungicides, instead relying on naturally derived products with a low risk for resistance selection, such as copper. However, repeated applications have resulted in elevated copper levels (Komárek and Chrastny 2008) that negatively impact soil invertebrates (Van-Zwieten et al. 2004) and alter the soil fungal community (Chu et al. 2010). In addition, phytotoxicity can occur on crops in which copper overuse has led to accumulation in soil (Adrees et al. 2015). Therefore, all fungicide spray programs must be carefully managed to achieve effective, ongoing disease management and to minimize nontarget effects.

One resistance management strategy is to rotate at-risk products with biorational ones, which suppress pathogen populations with a living organism (i.e., microbial biopesticide) or a natural compound derived from a living organism (i.e., biochemical biopesticide) (Marrone 2009). More than 200 biopesticide active ingredients have been registered in the United States (Chandler et al. 2011). Some of these biorational products are also listed by the Organic Materials Review Institute (OMRI), a nonprofit organization that evaluates products for compliance with United States Department of Agriculture organic standards. Although biorational products represent less than $3 \%$ of the overall pesticide market (Thakore 2006), they are valuable disease management tools for certified-organic and low-input produce operations. They also offer several advantages over synthetic products, including shorter restricted-entry and preharvest intervals (Marrone 2009). Examples of commercially available products for use in cucurbit production include Contans (which contains Coniothyrium minitans CON/M/91-08), Serenade (which contains Bacillus subtilis QST 713), and Messenger STS (which contains the resistance-inducing harpin protein).

Unfortunately, biorational products are generally more variable and less effective in managing diseases in field trials than conventional, synthetic fungicides. Previous studies in New York (McGrath and Shishkoff 1999) and Florida (Zhang et al. 2011) found that, while cucurbits treated with biorational products (such as Actinovate AG and Kaligreen) had significantly less powdery mildew than the nontreated control, the biorational products failed to provide the full-season powdery mildew management obtained with a conventional fungicide program. In a South Carolina field trial, tank-mixing a biorational product (such as Messenger, active ingredient harpin protein) with a conventional protectant fungicide (such as chlorothalonil) was statistically equivalent to the conventional fungicide applied alone in managing downy mildew severity on cantaloupe (Keinath et al. 2007). More recently, Matheron and Porchas (2013) determined the proportion of powdery mildew management on cantaloupe provided by each component within a rotational program that included biorational products and synthetic fungicides. They found that the synthetic fungicides (such as Procure, active ingredient triflumizole) provided the majority of the disease management, and alternating synthetic and biorational products (such as Actinovate AG) on a 7-day schedule did not result in greater powdery mildew disease management than applying a synthetic product alone on an extended 14-day schedule. Interestingly, there is a lack of published literature comparing the efficacy of biorational products with copper or sulfur fungicides, many of which are OMRI-listed, in organic vegetable production.

The objective of this study was to evaluate the efficacy of biorational products in an organic fungicide program against cucurbit downy mildew and powdery mildew under field conditions in Maryland. A preliminary account of some of this work has been reported (Everts and Newark 2014a, b).

\section{Materials and Methods}

Biorational products and copper fungicides. Four biorational products were tested in this study, i.e., Actinovate AG (active ingredient Streptomyces lydicus; Novozymes BioAg Inc., Milwaukee, WI), OxiDate (active ingredient hydrogen dioxide; BioSafe Systems, LLC, East Hartford, CT), Regalia (active ingredient Reynoutria sachalinesis extract; Marrone Bio Innovations, Davis, CA), and Serenade Soil applied as a foliar fungicide (active ingredient Bacillus subtilis; Bayer CropScience, Research Triangle Park, NC) (Table 1). Of the four biorational products, two are classified as microbial biopesticides (Actinovate AG and Serenade Soil) and two are classified as biochemical biopesticides (OxiDate and Regalia). A copper-based fungicide registered for both downy mildew and powdery mildew disease management in organic vegetable production was included as a commercial standard and positive control. In 2013, Champ WG (active ingredient copper hydroxide; NuFarm Americas, Inc., Burr Ridge, IL) was tested. In 2014, Champ WG was replaced with Cueva (active ingredient copper octanoate; Certis USA, LLC, Columbia, MD), which has a shorter re-entry interval ( $4 \mathrm{~h}$ versus $48 \mathrm{~h}$ ) and is less phytotoxic. Nontreated plots served as the negative control.

Field experiments. Field trials were conducted in 2013 (trials 1 and 2) and 2014 (trial 3) at the University of Maryland Lower Eastern Shore Research and Education Center (UMD-LESREC) in a loamy sand soil with a $\mathrm{pH}$ of 6.9. Field trials were conducted on land that has been managed with organic practices for 11 years and is registered exempt from organic certification, which means that the production practices are in compliance with the Maryland Department of Agriculture's Organic Certification Program, but the farm is exempt from certification because the produce is not sold (i.e., gross agricultural income from organic sales is zero). Fall-seeded annual cover crops (cereal rye in 2012-2013; a 4:1 mixture of cereal rye and crimson clover in 2013-2014) were established in each location to maintain soil fertility and were mowed and incorporated into the soil in the spring. The experimental design for each trial was a split plot design (main plots, fungicide treatment; subplots, cucurbit species) with four replications. A copper fungicide was applied once a week alone or in a rotation program with a biorational product to the four cucurbit crops, i.e., cucumber ('Marketmore 76'; moderate resistance to downy mildew and powdery mildew), muskmelon ('Arava'; susceptible to downy mildew, moderate resistance to powdery mildew), pumpkin ('Howden'; susceptible to downy mildew and powdery mildew), and butternut squash ('Waltham Butternut'; susceptible to downy mildew and powdery mildew). In 2014, an additional fungicide treatment was added to determine the foliar disease management provided by copper applied alone on a 14-day schedule. Fungicides were applied with an ATV-mounted, $\mathrm{CO}_{2}$-pressurized

Table 1. Fungicide information

\begin{tabular}{lllll}
\hline Product $^{\mathbf{x}}$ & Rate $^{\mathbf{y}}$ & \multicolumn{1}{c}{ Active ingredient } & \multicolumn{1}{c}{ Manufacturer $^{\text {FRAC code }^{\mathbf{z}}}$} \\
\hline Actinovate AG & $0.9 \mathrm{liter}$ & Streptomyces lydicus WYEC 108 & Novozymes BioAg Inc., Milwaukee, WI \\
OxiDate & $3.5 \mathrm{liter}$ & Hydrogen dioxide & BioSafe Systems, LLC, East Hartford, CT & n/a \\
Regalia & $2.3 \mathrm{liter}$ & Extract of Reynoutria sachalinesis & Marrone Bio Innovations, Davis, CA & P5 \\
Serenade Soil & $4.7 \mathrm{liter}$ & Bacillus subtilis QST 713 & Bayer CropScience, Research Triangle Park, NC \\
Champ WG & $0.9 \mathrm{~kg}$ & Copper hydroxide & NuFarm Americas, Inc., Burr Ridge, IL & M4 \\
Cueva & 19 liter & Copper octanoate & Certis USA, LLC, Columbia, MD & M1 \\
\hline
\end{tabular}

${ }^{x}$ No adjuvants were applied with any of the tested products.

y Per hectare.

${ }^{\mathrm{z}}$ FRAC codes from the Fungicide Resistance Action Committee. 
backpack sprayer with four TeeJet VS11004 flat fan nozzles (TeeJet Technologies, Wheaton, IL) spaced $48.3 \mathrm{~cm}$ apart and calibrated to deliver 421 liters $\mathrm{ha}^{-1}$ at $290 \mathrm{kPa}$. Treatments began at 40 days (2013 trials) and 30 days (2014 trial) after planting, when no symptoms of downy mildew were present in the on-site sentinel plots, and continued until crop maturity. Each plot received a total of seven fungicide applications per trial per year. Cucurbits were infected by naturally occurring downy mildew and powdery mildew pathogen populations. SoilGard (Certis USA) was applied to all cucurbits at planting at a rate of $2.4 \mathrm{~g} \mathrm{liter}^{-1}$ to manage Pythium species and Sclerotinia rolfsii. Air temperature, relative humidity, and precipitation were recorded hourly at an on-site meteorological station (CR1000 data logger; Campbell Scientific, Logan, UT). Plots were monitored twice weekly for both downy mildew and powdery mildew. Downy mildew severity was evaluated as the percent of the lower (abaxial) leaf area covered with sporulation on three to five random leaves within a plot. Powdery mildew severity was evaluated both as the proportion of the upper (adaxial) and lower leaf surface area ( 0 to $100 \%$ ) covered with pathogen sporulation on five random leaves located in the middle part of the canopy within a plot, avoiding both the old and young leaves. Cucumber beetles were managed as needed by applying AzaGuard (BioSafe Systems, LLC) at $0.6 \mathrm{~kg} \mathrm{ha}^{-1}$ or Entrust SC (Dow AgroSciences, Indianapolis, IN) at $0.2 \mathrm{~kg} \mathrm{ha}^{-1}$. Weeds were managed with weekly mechanical or hand cultivation.

Field trials on cucurbits in 2013. In field trial 1, cucumber and muskmelon were transplanted on May 24, while in field trial 2, pumpkin and butternut squash were direct-seeded on May 31. Cucumber was spaced $0.5 \mathrm{~m}$ apart within the row; muskmelon, pumpkin, and butternut squash were spaced $0.9 \mathrm{~m}$ apart within the row. Each plot consisted of a single raised bed $7.3 \mathrm{~m}$ long on 2.1-m (trial 1) or 2.4-m (trial 2) centers, covered with black polyethylene mulch. A total of 16 cucumber, eight muskmelon, eight pumpkin, or eight butternut squash plants were within each plot. Fallow buffer zones (about $0.9 \mathrm{~m}$ wide) were maintained between plots, and a border row of winter squash (2.4 m wide) was maintained between the two experiments as well as on the north side of trial 1 and on the south side of trial 2. Cucurbits were irrigated as needed with a drip-tape

Table 2. Foliar disease severity in organic trial 1 under field conditions in 2013

\begin{tabular}{lcc}
\hline & \multicolumn{2}{c}{ Disease severity $(\%)$} \\
\cline { 2 - 3 } Crop, treatments & Powdery mildew & Downy mildew \\
\hline Cucumber & $0 \mathrm{~d}$ & $20.3 \mathrm{~cd}$ \\
Actinovate AG alt. Champ WG ${ }^{\mathrm{z}}$ & $0 \mathrm{~d}$ & $49.5 \mathrm{~b}$ \\
OxiDate alt. Champ WG & $0 \mathrm{~d}$ & $27.2 \mathrm{c}$ \\
Regalia alt. Champ WG & $0 \mathrm{~d}$ & $19.1 \mathrm{~cd}$ \\
Serenade Soil alt. Champ WG & $0 \mathrm{~d}$ & $13.8 \mathrm{~cd}$ \\
Champ WG (7-day schedule) & $0 \mathrm{~d}$ & $88.3 \mathrm{a}$ \\
Nontreated & & \\
Muskmelon & $16.3 \mathrm{bc}$ & $14.8 \mathrm{~cd}$ \\
Actinovate AG alt. Champ WG & $14.0 \mathrm{bc}$ & $9.7 \mathrm{~d}$ \\
OxiDate alt. Champ WG & $17.0 \mathrm{bc}$ & $7.7 \mathrm{~d}$ \\
Regalia alt. Champ WG & $10.2 \mathrm{c}$ & $9.7 \mathrm{~d}$ \\
Serenade Soil alt. Champ WG & $21.9 \mathrm{~b}$ & $8.3 \mathrm{~d}$ \\
Champ WG (7-day schedule) & $34.3 \mathrm{a}$ & $58.3 \mathrm{~b}$ \\
$\quad$ Nontreated & 3.3013 & 5.4137 \\
Standard error & 0.0005 & 0.0001 \\
$P$ > F cucurbit crop (C) & 0.0398 & 0.0001 \\
Biorational product (BP) & 0.0002 & 0.0001 \\
Interaction (C $\times$ BP) &
\end{tabular}

y Powdery mildew and downy mildew severity evaluated as the percent of the lower leaf surface covered with sporulation on three to five random leaves within a plot. Both diseases rated on August 27, 2013. Means within a column followed by the same letter are not significantly different $(P=0.05)$ according to Fisher's least significant difference test.

${ }^{\mathrm{z}}$ Treatment dates for trial 1 were July 5, 15, 22, and 30 and August 7, 13, and $20,2013$. system. Disease severity of downy mildew was rated on August 8 and 27 (trial 1) and September 4 (trial 2). Disease severity of powdery mildew was rated on August 8 and 27 (trial 1) and July 30 and August 5 (trial 2). Marketable fruit and culls (cucumber only) were harvested two to eight times for each cucurbit crop, and the number, weight, and total yields were recorded for each plot for data analysis.

Field trial on cucurbits in 2014. In trial 3, all cucurbits were transplanted on June 2. Cucumber was spaced $0.5 \mathrm{~m}$ apart within the row; muskmelon, pumpkin, and butternut squash were spaced $0.6 \mathrm{~m}$ apart within the row. Each plot consisted of a single raised bed $5.5 \mathrm{~m}$ long on $2.1-\mathrm{m}$ centers, covered with black polyethylene mulch. A total of 18 cucumber, nine muskmelon, nine pumpkin, or nine butternut squash plants were transplanted into each plot. Fallow buffer zones (about $0.9 \mathrm{~m}$ wide) were maintained between plots, and a border row of winter squash ( $2.4 \mathrm{~m}$ wide) was maintained on the north and south sides of the field. Cucurbits were irrigated, as needed, with a drip-tape system. Downy mildew disease severity was rated on July 21 and on August 6 and 26. Powdery mildew disease severity was rated on July 21. Marketable fruit and culls (cucumber only) were harvested one to twelve times for each cucurbit crop, and the number, weight, and total yields were recorded for each plot for data analysis.

Statistical analysis. Data from both years were analyzed together as a split-split plot; however, there was a significant year $\times$ crop $\times$ fungicide interaction. Therefore, data from each year was subsequently analyzed separately, using a mixed model. Fixed effects were cucurbit crop and fungicide treatment, while replication was treated as a random effect. Least square means were calculated with standard error. Statistically significant effect was $P<0.05$ when further analyzed with Fisher's least significant difference (LSD) test for downy mildew and powdery disease severity or with Tukey's honest significant difference (HSD) test for yield. All analysis was performed using either SAS ver. 9.4 or JMP Pro ver.11 (SAS Institute Inc., Cary, NC).

\section{Results}

Disease development and climatic factors. In 2013, downy mildew was first observed in on-site sentinel plots on July 15 (cucumber), July 31 (muskmelon), August 5 (butternut squash), and August 22 (pumpkin). The date powdery mildew colonies were initially detected in the field was not recorded in 2013. Average daily maximum and minimum temperatures for June, July, and August were 29 and $19^{\circ} \mathrm{C}, 32$ and $23^{\circ} \mathrm{C}$, and 29 and $19^{\circ} \mathrm{C}$, respectively. Mean relative humidity levels were $84 \%$ throughout the season. A total of 378, 264, and $168 \mathrm{~mm}$ of precipitation were recorded in June, July, and August, respectively.

In 2014, downy mildew was first observed in on-site sentinel plots on July 11 (cucumber), August 4 (muskmelon and pumpkin), and August 28 (butternut squash). Powdery mildew colonies were initially detected on muskmelon on July 14 . Average daily maximum and minimum temperatures for June, July, August, and September were 28 and $16^{\circ} \mathrm{C}, 29$ and $18^{\circ} \mathrm{C}, 21$ and $16^{\circ} \mathrm{C}$, and 25 and $14^{\circ} \mathrm{C}$, respectively. Mean relative humidity levels ranged from 69 (June) to $78 \%$ (September) during the season. A total of 27, 85, 125, and $112 \mathrm{~mm}$ of precipitation were recorded in June, July, August, and September, respectively.

Efficacy of biorational products applied in alteration with copper on cucurbit downy mildew. Field trials in 2013. For downy mildew severity in trial 1 , there was a significant $(P<0.001)$ crop $x$ fungicide treatment interaction. Downy mildew was severe on all nontreated cucurbit plants by crop maturity, with mean values ranging from 58 (muskmelon) to $88 \%$ (cucumber) of the leaf surface covered with Pseudoperonospora cubensis in the nontreated plots in 2013 (Table 2). In field trial 1 on cucumber and muskmelon, all treatments alternating copper with a biorational product resulted in significantly $(P<0.001)$ lower downy mildew disease severity, as compared with the nontreated plants. However, the level of disease management provided by the biorational products was not significantly different than that provided by weekly applications of copper alone for either crop, with one exception (Table 2). On cucumber, copper applied in rotation with OxiDate performed significantly worse, in terms of downy mildew disease management, than treatments alternating copper 
with Actinovate AG, Regalia, or Serenade Soil or copper applied alone on a 7-day schedule (Table 2).

For downy mildew severity in trial 2 , the crop $\times$ fungicide treatment interaction was not significant $(P=0.070)$. In field trial 2 on pumpkin, copper applied in rotation with Serenade Soil significantly reduced downy mildew severity, as compared with the nontreated plants (Table 3). However, disease severity in plots that received copper applied in rotation with Regalia was not significantly different from the nontreated pumpkin control. For butternut squash, all treatments alternating copper with a biorational product resulted in significantly $(P<0.001)$ lower downy mildew disease severity, as compared with the nontreated plants (Table 3). However, the level of disease management provided by the biorational products was not significantly different than that provided by weekly applications of copper alone for both pumpkin and butternut squash (Table 3).

Field trial in 2014. For downy mildew severity in trial 3, there was a significant $(P<0.001)$ crop $\times$ fungicide treatment interaction. In field trial 3 , downy mildew was severe on nontreated cucumber and muskmelon plants by crop maturity, with mean values of 72 and $78 \%$ of the leaf surface covered with Pseudoperonospora cubensis in the nontreated plots in 2014 (Table 4). A lower level of disease was present on the remaining cucurbit crops, in which the initial onset of downy mildew occurred later. For cucumber, treatments alternating copper with Actinovate AG, OxiDate, Regalia, or Serenade Soil resulted in significantly $(P<0.001)$ lower downy mildew severity, as compared with the nontreated plants (Table 4). However, disease severity in these plots was not significantly different from plots receiving either the 7-day or 14-day copper schedule, indicating that the addition of the biorational product did not reduce downy mildew severity. For muskmelon, all biorational products reduced downy mildew severity, as compared with the nontreated control (Table 4). Treatments alternating copper with Actinovate AG or OxiDate resulted in significantly $(P<0.001)$ lower downy mildew severity than the 14-day copper schedule, while treatments alternating copper with Regalia or Serenade Soil were statistically equivalent to the extended copper spray interval. However, the level of disease management provided by the biorational products was significantly worse than that provided by the weekly copper applications. For

Table 3. Foliar disease severity in organic trial 2 under field conditions in 2013

\begin{tabular}{lcc}
\hline & \multicolumn{2}{c}{ Disease severity ${ }^{\mathbf{y}}(\%)$} \\
\cline { 2 - 3 } Crop, treatments & Powdery mildew & Downy mildew \\
\hline Pumpkin & $\mathrm{NT}$ & $\mathrm{NT}$ \\
Actinovate AG alt. Champ WG & $\mathrm{z}$ & $\mathrm{NT}$ \\
OxiDate alt. Champ WG & $\mathrm{NT}$ & $52.6 \mathrm{abc}$ \\
Regalia alt. Champ WG & $21.0 \mathrm{~b}$ & $26.5 \mathrm{~cd}$ \\
Serenade Soil alt. Champ WG & $18.4 \mathrm{~b}$ & $41.5 \mathrm{bcd}$ \\
Champ WG (7-day schedule) & $28.2 \mathrm{~b}$ & $82.8 \mathrm{a}$ \\
Nontreated & $74.7 \mathrm{a}$ & \\
Butternut squash & & $\mathrm{NT}$ \\
Actinovate AG alt. Champ WG & $\mathrm{NT}$ & $\mathrm{NT}$ \\
OxiDate alt. Champ WG & $\mathrm{NT}$ & $26.0 \mathrm{~cd}$ \\
Regalia alt. Champ WG & $3.7 \mathrm{~b}$ & $34.9 \mathrm{~cd}$ \\
Serenade Soil alt. Champ WG & $5.7 \mathrm{~b}$ & $15.9 \mathrm{~d}$ \\
Champ WG (7-day schedule) & $4.7 \mathrm{~b}$ & $68.6 \mathrm{ab}$ \\
Nontreated & $10.4 \mathrm{~b}$ & 13.1688 \\
Standard error & 8.1569 & 0.2589 \\
$P$ > F cucurbit crop (C) & 0.0414 & 0.0043 \\
Biorational product (BP) & 0.0011 & 0.0704 \\
Interaction (C $\times$ BP) & 0.0001 & \\
\hline
\end{tabular}

y Powdery mildew and downy mildew severity evaluated as the percent of the lower leaf surface covered with sporulation on three to five random leaves within a plot. Powdery mildew rated on August 5, 2013; downy mildew rated on September 4, 2013. Means within a column followed by the same letter are not significantly different $(P=0.05)$ according to Fisher's least significant difference test.

$\mathrm{z}$ Treatment dates for trial 2 were July 10,18, and 25 and August 1, 8, 14, and 21,2013 . NT $=$ product not tested on that cucurbit that year. pumpkin, there were no significant differences among treatments (Table 4), although downy mildew severity was up to $71 \%$ lower on plants that received the biorational products compared with the nontreated plants. For butternut squash, where disease severity was low and averaged only $2.3 \%$ across all treatments, none of the biorational products significantly reduced downy mildew severity, as compared with the nontreated plants (Table 4). It was unexpected that extending the copper spray interval (14- versus 7-day schedule) resulted in a significant increase in downy mildew disease severity on muskmelon but not on the other cucurbit crops.

Efficacy of biorational products applied in alteration with copper on cucurbit powdery mildew. Field trials in 2013. In field trial 1, powdery mildew was absent from cucumber plants in both the nontreated and treated plots by crop maturity (Table 2). For muskmelon, in which a moderate level of disease was present (mean value of $29 \%$ of total upper and lower leaf surface covered with Podosphaera xanthii) in the nontreated plots, all treatments alternating copper with a biorational product resulted in significantly $(P<0.001)$ lower powdery mildew on the lower leaf surface but not the upper leaf surface (data not shown), as compared with the nontreated plants (Table 2). However, the level of disease management provided by the

Table 4. Foliar disease severity in organic trial 3 under field conditions in 2014

\begin{tabular}{|c|c|c|}
\hline \multirow[b]{2}{*}{ Crop, treatments } & \multicolumn{2}{|c|}{ Disease severity ${ }^{\mathrm{y}}(\%)$} \\
\hline & Powdery mildew & Downy mildew \\
\hline \multicolumn{3}{|l|}{ Cucumber } \\
\hline Actinovate AG alt. Cueva ${ }^{\mathrm{z}}$ & $0.0 \mathrm{f}$ & $28.8 \mathrm{efgh}$ \\
\hline OxiDate alt. Cueva & $0.0 \mathrm{f}$ & 33.0 defg \\
\hline Regalia alt. Cueva & $0.0 \mathrm{f}$ & $39.8 \mathrm{cdef}$ \\
\hline Serenade Soil alt. Cueva & $0.9 \mathrm{f}$ & 44.8 cde \\
\hline Cueva (7-day schedule) & $0.0 \mathrm{f}$ & $38.6 \mathrm{cdef}$ \\
\hline Cueva (14-day schedule) & $5.7 \mathrm{f}$ & 42.0 cde \\
\hline Nontreated & $0.9 \mathrm{f}$ & $71.9 \mathrm{ab}$ \\
\hline \multicolumn{3}{|l|}{ Muskmelon } \\
\hline Actinovate AG alt. Cueva ${ }^{\mathrm{z}}$ & $1.2 \mathrm{f}$ & $51.8 \mathrm{c}$ \\
\hline OxiDate alt. Cueva & $0.2 \mathrm{f}$ & $48.8 \mathrm{~cd}$ \\
\hline Regalia alt. Cueva & $0.4 \mathrm{f}$ & $54.1 \mathrm{bc}$ \\
\hline Serenade Soil alt. Cueva & $0.4 \mathrm{f}$ & $54.4 \mathrm{bc}$ \\
\hline Cueva (7-day schedule) & $0.4 \mathrm{f}$ & 20.2 ghij \\
\hline Cueva (14-day schedule) & $0.2 \mathrm{f}$ & $70.3 \mathrm{ab}$ \\
\hline Nontreated & $0.9 \mathrm{f}$ & $78.3 \mathrm{a}$ \\
\hline \multicolumn{3}{|l|}{ Pumpkin } \\
\hline Actinovate AG alt. Cueva ${ }^{\mathrm{z}}$ & $79.0 \mathrm{ab}$ & $6.2 \mathrm{ijk}$ \\
\hline OxiDate alt. Cueva & $78.0 \mathrm{ab}$ & 12.6 hijk \\
\hline Regalia alt. Cueva & $68.2 \mathrm{~b}$ & $7.3 \mathrm{ijk}$ \\
\hline Serenade Soil alt. Cueva & $87.8 \mathrm{a}$ & $6.7 \mathrm{ijk}$ \\
\hline Cueva (7-day schedule) & $73.7 \mathrm{~b}$ & $7.1 \mathrm{ijk}$ \\
\hline Cueva (14-day schedule) & $77.4 \mathrm{ab}$ & $7.0 \mathrm{ijk}$ \\
\hline Nontreated & $87.0 \mathrm{a}$ & 21.4 fghi \\
\hline \multicolumn{3}{|l|}{ Butternut squash } \\
\hline Actinovate AG alt. Cuevaz & $21.7 \mathrm{e}$ & $7.6 \mathrm{ijk}$ \\
\hline OxiDate alt. Cueva & $29.3 \mathrm{de}$ & $2.6 \mathrm{jk}$ \\
\hline Regalia alt. Cueva & $42.6 \mathrm{c}$ & $1.6 \mathrm{k}$ \\
\hline Serenade Soil alt. Cueva & $22.2 \mathrm{de}$ & $2.6 \mathrm{jk}$ \\
\hline Cueva (7-day schedule) & $23.4 \mathrm{de}$ & $1.6 \mathrm{k}$ \\
\hline Cueva (14-day schedule) & $33.2 \mathrm{~cd}$ & $0.0 \mathrm{k}$ \\
\hline Nontreated & $43.8 \mathrm{c}$ & $0.0 \mathrm{k}$ \\
\hline Standard error & 4.8929 & 6.7430 \\
\hline$P>$ F Cucurbit crop $(\mathrm{C})$ & 0.0001 & 0.0001 \\
\hline Biorational product (BP) & 0.3979 & 0.0067 \\
\hline Interaction $(\mathrm{C} \times \mathrm{BP})$ & 0.0001 & 0.0001 \\
\hline
\end{tabular}

y Powdery mildew and downy mildew severity evaluated as the percent of the lower leaf surface covered with sporulation on three to five random leaves within a plot. Powdery mildew rated on July 21,2014 ; downy mildew rated on August 26, 2014. Means within a column followed by the same letter are not significantly different $(P=0.05)$ according to Fisher's least significant difference test.

${ }^{\mathrm{z}}$ Treatment dates were July 1, 8, 15, 22 and 29 and August 5 and 12, 2014. 
biorational products was not significantly different than that provided by copper alone for muskmelon in trial 1 , except for the Serenade Soil treatment, which reduced powdery mildew by $53 \%$ compared with the 7-day copper schedule. There was also a significant crop $\times$ fungicide treatment interaction for lower $(P<0.001)$ but not upper $(P=0.116)$ leaf surface powdery mildew in trial 1 (Table 2$)$.

In field trial 2 , powdery mildew was severe on nontreated pumpkin plants by crop maturity, with a mean value of $47 \%$ of the total upper and lower leaf surface covered with Podosphaera xanthii. Treatments alternating copper with Regalia or Serenade Soil significantly $(P<0.001)$ reduced powdery mildew severity on the upper (data not shown) and lower leaf surfaces of pumpkin, as compared with the nontreated plants (Table 3). For butternut squash, in which a lower level of disease was present (mean upper and lower leaf surface severity of 7\%) in the nontreated plots, no treatment significantly reduced powdery mildew severity on the lower leaf surface compared with the nontreated control (Table 3). Copper applied in rotation with Serenade Soil significantly reduced powdery mildew severity on the upper leaf surface of butternut squash, as compared with the nontreated plants (data not shown). For both pumpkin and butternut squash in trial 2, the level of disease management provided by the biorational products was not significantly different from that provided by copper alone (Table 3$)$. There was also a significant $(P<$ $0.001)$ crop $\times$ fungicide treatment interaction for both upper and lower leaf powdery mildew in trial 2 .

Field trial in 2014. In field trial 3, powdery mildew disease pressure was low on cucumber and muskmelon, with mean values of 1 and $3 \%$ of the total upper and lower leaf surface of nontreated plants covered with sporulation of Podosphaera xanthii. Treatments alternating copper with a biorational product were not significantly different from the nontreated control for powdery mildew severity on the upper and lower leaf surfaces of cucumber $(P=0.128$ and $P=0.355$, respectively) or the lower leaf surface of muskmelon $(P=0.427)$. However, treatments alternating copper with Actinovate AG, OxiDate, Regalia or Serenade Soil resulted in significantly $(P=0.001)$ lower powdery mildew severity on the upper leaf surface of muskmelon, as compared with the nontreated plants (data not shown). For pumpkin, in which a higher level of disease was present (mean upper and lower leaf surface severity of $76 \%$ ) in the nontreated plots, all treatments alternating copper with a biorational product significantly $(P<0.001)$ reduced powdery mildew on the upper leaf surface (data not shown) but not on the lower leaf surface, on which only Regalia alternated with copper reduced powdery mildew compared with the nontreated plants (Table 4). For butternut squash, in which a moderate level of disease was present (mean upper and lower leaf surface severity of $38 \%$ ), treatments alternating copper with Actinovate AG, OxiDate, or Serenade Soil significantly $(P \leq 0.001)$ reduced powdery mildew severity on the lower leaf surface, as compared with the nontreated plots (Table 4). Treatments alternating copper with Actinovate AG significantly reduced powdery mildew severity on the lower leaf surface of butternut squash, as compared

Table 5. Effect of fungicides applied alone or in a rotational program on cucurbit marketable yield in trial 1 in 2013

\begin{tabular}{|c|c|c|c|c|}
\hline \multirow[b]{3}{*}{ Product } & \multicolumn{4}{|c|}{ Marketable fruit yield } \\
\hline & \multicolumn{2}{|c|}{ Cucumber $^{y}$} & \multicolumn{2}{|c|}{ Muskmelon $^{\mathrm{z}}$} \\
\hline & $\mathbf{N}$ & $\overline{\mathrm{kg} / \mathrm{plot}}$ & $\overline{\mathbf{N}}$ & kg/fruit \\
\hline Actinovate AG alt. Champ WG & 140 & 12.2 & 47 & 3.7 \\
\hline OxiDate alt. Champ WG & 115 & 7.8 & 38 & 3.1 \\
\hline Regalia alt. Champ WG & 124 & 11.0 & 51 & 3.3 \\
\hline Serenade Soil alt. Champ WG & 136 & 11.3 & 29 & 2.1 \\
\hline Champ WG (7-day schedule) & 115 & 8.4 & 33 & 2.5 \\
\hline Nontreated & 119 & 8.8 & 42 & 3.3 \\
\hline$P>$ F Fungicides & & 0.7354 & & 0.5906 \\
\hline
\end{tabular}

y Cucumber harvested eight times: 25 and 29 July; and 5, 9, 15, 19, 26 and 29 August 2013.

${ }^{\mathrm{z}}$ Muskmelon harvested six times: 2, 9, 15, 19, 26 and 29 August 2013. Data on percent Brix not collected during this field trial. with plants treated with the 14-day copper schedule. However, for all cucurbit crops in trial 3, the level of disease management provided by the biorational products was not significantly different than that provided by the 7-day copper schedule (Table 4). Powdery mildew disease severity was also not impacted on any cucurbit by extending the copper spray interval (7- versus 14-day schedule). The interaction of crop $\times$ fungicide treatment was significant $(P<0.001)$ for both upper and lower leaf powdery mildew severity in trial 3.

Impact of biorational products applied in alteration with copper on marketable yield. Field trials in 2013. In field trial 1, all treatments were statistically equivalent to the control in terms of yield, for both cucumber and muskmelon $(P=0.735$ and $P=$ 0.591 , respectively) (Table 5). The number of marketable fruit and culls (cucumber only; data not shown) harvested in plots treated with a biorational product was also not significantly different from that of nontreated plots (cucumber, $P=0.965$ and $P=0.495$, respectively; muskmelon, $P=0.503$ ). In field trial 2 , marketable yield was low for all treatments of pumpkin and butternut squash at crop maturity (data not shown), due to plant death from bacterial wilt.

Field trial in 2014. In field trial 3, the yields for cucumber, pumpkin, and butternut squash treated with biorational products were statistically equivalent to the nontreated control across all treatments ( $P=0.763, P=0.851$, and $P=0.877$, respectively) (Table 6). Additionally, the number of marketable fruit and culls (cucumber only; data not shown) harvested in plots treated with a biorational product was not significantly different from that of nontreated plots for cucumber $(P=0.968$ and $P=0.382$, respectively) or butternut squash $(P=0.692)$. For muskmelon, alternating applications of copper with Actinovate AG significantly $(P=0.002)$ increased the average fruit size compared with treatments including Regalia, but all treatments were statistically equivalent to the control. The percent soluble sugars and number of marketable fruit harvested in muskmelon plots treated with a biorational product were also not significantly different ( $P=0.347$ and $P=0.995$, respectively) from that of nontreated plots (Table 6). There were no differences in yield between the 7- and 14-day copper schedules for any cucurbit.

\section{Discussion}

When applied in rotation with copper, all of the biorational products evaluated in this study generally reduced downy mildew and powdery mildew on field-grown cucumber, muskmelon, pumpkin, and butternut squash, as compared with the nontreated plots. The efficacy of the individual biorational products tested in 2013 and 2014 on foliar cucurbit diseases ranged from a 16 to $69 \%$ reduction in downy mildew and from a 7 to $59 \%$ reduction in powdery mildew, as compared with the control. Growers may seek to reduce copper applications for environmental or crop-health reasons. Treatments alternating copper with Actinovate AG, OxiDate, or Serenade Soil reduced either downy mildew or powdery mildew severity in at least one cucurbit crop in comparison with copper applied alone on a 7- or 14-day schedule. These rotational programs may help growers reduce copper applications and improve disease management, but they did not provide greater disease management or improve marketable yield compared with a copper-only fungicide program on a 7-day schedule. The materials evaluated in this study may have performed better if the pesticide application equipment dedicated to organic production at UMD-LESREC had had more thorough spray coverage on the leaf underside.

Organic growers often express that they prefer to see efficacy trials for biorational products conducted under organic practices. Here, we have demonstrated that these products vary in their performance under field conditions in an organic production system compared with OMRI-listed copper fungicides. Previous studies have also documented that biorational products applied alone (McGrath and Shishkoff 1999; Zhang et al. 2011), in combination (Janousek et al. 2009), or in tank mixes with conventional fungicides (Keinath et al. 2007; Matheron and Porchas 2013) do not perform better under field conditions in terms of cucurbit foliar disease reduction than the conventional fungicide applied alone. And although integrating biorational products into disease management programs has been associated 
with a yield increase in other vegetable crops (Estevez de Jensen et al. 2002; Wszelaki and Miller 2005), this was not observed in our or other cucurbit field trials (Rideout et al. 2010; Zhang et al. 2011). The lack of yield differences observed in these trials, particularly in 2014, likely resulted from the late onset of downy mildew. On the eastern shore of Maryland (where this study took place) and in Delaware, the first date of downy mildew observation varies by year and by cucurbit crop species. For example, from 2011 to 2015, the earliest and latest downy mildew onsets recorded, respectively, were June 13 and July 6 on cucumber, July 17 and August 15 on muskmelon, August 8 and September 21 on Cucurbita pepo; and June 27 and not present on watermelon. This demonstrates that biorational products have the potential to reduce disease and improve yield in some years but not others. Consequently, the challenge remains on how to most effectively use biorational products, especially on organically managed vegetables.

One common recommendation is to use biorational products as alternation partners with at-risk fungicides as a resistance management strategy. Generally, synthetic fungicides with a single-site mode of action are at a higher risk of resistance development than products with multisite activity. According to mathematical models, the rate of resistance development within a plant pathogen population can be delayed but not prevented with this rotational approach (Brent and Hollomon 2007; van den Bosch et al. 2015). The ability of the biorational product to dilute the selection pressure of the at-risk fungicide and to inhibit the growth of resistant isolates may, therefore, be more important than the product's individual efficacy (Matheron and Porchas 2013). However, this recommendation for biorational products is less applicable for organic production, which prohibits the use of synthetic fungicides. Long-term follow-up data on the effect of biorational partner fungicides on the development of resistance to at-risk fungicides are also lacking. Nonetheless, disease management programs may be improved if biorational products are applied preventatively (i.e., before anticipated disease symptoms appear) or if shorter spray intervals are used (McGrath and Shishkoff 1999). Postharvest disease management in vegetables using biorational products also appears promising (Sharma et al. 2009). More generally, grower adoption of biorational products would benefit from additional research on adjuvant selection and droplet size, as both factors impact the coverage and efficacy of foliar contact fungicides (Gent et al. 2003; Prokop and Veverka 2006), including microbial biopesticides (Gan-Mor and Matthews 2003).

Another opportunity for biorational products is in complementing crop cultivars with quantitative disease resistance, an incomplete but more durable form of resistance (Poland et al. 2009). This is particularly relevant for organic agriculture, as commercially desirable, non-genetically modified cultivars are often unavailable or lacking traits necessary for low-input production (Crespo-Herrera and Ortiz 2015; Lammerts van Bueren et al. 2011). In this study, we selected cucurbit cultivars with susceptibility or moderate resistance to one or both downy mildew and powdery mildew. As expected, there was a significant interaction between cucurbit crop and fungicide treatment for both foliar cucurbit diseases. Nontreated cucumber ('Marketmore 76', moderately resistant) plots had the highest downy mildew disease severity (mean lower leaf surface severity of $80 \%$ ), but plants treated with biorational products also had the greatest disease reductions, ranging from 39 to $56 \%$ (OxiDate and Actinovate AG treatments, respectively). This data supports an earlier metaanalysis by Ojiambo et al. (2010), who found that fungicide efficacy against cucurbit downy mildew was greater for susceptible cucumber cultivars than for susceptible cultivars of other cucurbits, including muskmelon and pumpkin. The interaction between cucurbit crop and fungicide treatment is likely complicated by the number of different pathotypes and races of Pseudoperonospora cubensis and Podosphaera xanthii and the high level of genetic diversity within and among pathogen isolates (Lebeda et al. 2016; QuesadaOcampo et al. 2012). For example, previous work in Botrytis cinerea (a common pathogen in greenhouse vegetable production) has demonstrated that diversity within the pathogen population is associated with the variable performance of biorational products, regardless of their mode of action (Nicot et al. 2016). Under high disease pressure, biorational products may also be insufficient to manage disease or minimize yield loss on susceptible crop cultivars.

Published literature also suggests that biorational products may be better suited for use in protected cropping or greenhouses than in open-field production. For example, applications of the biorational product BU EXP 1216S (active ingredient Bacillus subtilis MBI600) reduced powdery mildew on cucurbits $70 \%$ in greenhouse experiments but only $20 \%$ in field experiments, as compared with the water control (Zhang et al. 2011). Gilardi et al. (2012) also reported greater powdery mildew disease management on zucchini squash from biorational products applied in a greenhouse setting than in the field. This discrepancy in performance is likely due to unfavorable conditions in the field environment (Reddy 2016), as biorational products containing a living organism are sensitive to fluctuations in temperature, relative humidity, soil moisture, and solar radiation (Partridge et al. 2006; Romero et al. 2007). Unfortunately, the tightly controlled environment in protected cropping has its own risks. Greenhouses may serve as a manmade reservoir of cucurbit downy mildew, as year-round cucumber production in Michigan and Canada provides Pseudoperonospora cubensis with the opportunity for prolonged growth and protection from killing frost (Cohen et al. 2015). For Maryland and other northern states, this 'green bridge' may also be an important source of early inoculum (Cohen et al. 2015) and fungicide-resistant isolates (Brent and Hollomon 2007; Zhu et al. 2007). Greenhouse use of biorational products could be an effective way to minimize selection pressure and reduce early season pathogen populations before they reach organic vegetable fields.

Table 6. Effect of fungicides applied alone or in a rotational program on cucurbit marketable yield in trial 3 in 2014

\begin{tabular}{|c|c|c|c|c|c|c|c|c|c|}
\hline \multirow[b]{3}{*}{ Product } & \multicolumn{9}{|c|}{ Marketable fruit yield } \\
\hline & \multicolumn{2}{|c|}{ Cucumber $^{w}$} & \multicolumn{3}{|c|}{ Muskmelon $^{\mathrm{x}}$} & \multicolumn{2}{|c|}{ Pumpkiny } & \multicolumn{2}{|c|}{ Butternut squash ${ }^{\mathrm{z}}$} \\
\hline & $\mathbf{N}$ & kg/plot & $\mathbf{N}$ & kg/fruit & $\%$ Brix & $\mathbf{N}$ & kg/fruit & $\mathbf{N}$ & kg/plot \\
\hline Actinovate AG alt. Cueva & 456 & 30.3 & 69 & $1.7 \mathrm{a}$ & 8.8 & 10 & 3.5 & 49 & 13.4 \\
\hline OxiDate alt. Cueva & 293 & 17.7 & 65 & $1.6 \mathrm{ab}$ & 8.2 & 11 & 3.7 & 66 & 17.0 \\
\hline Regalia alt. Cueva & 418 & 27.9 & 70 & $1.4 \mathrm{~b}$ & 8.3 & 7 & 3.4 & 61 & 15.7 \\
\hline Serenade Soil alt. Cueva & 400 & 23.9 & 57 & $1.5 \mathrm{ab}$ & 8.6 & 10 & 3.5 & 55 & 15.5 \\
\hline Cueva (7-day schedule) & 410 & 24.9 & 85 & $1.7 \mathrm{a}$ & 9.1 & 5 & 4.2 & 66 & 16.5 \\
\hline Cueva (14-day schedule) & 411 & 26.9 & 60 & $1.7 \mathrm{a}$ & 8.4 & 11 & 4.1 & 57 & 15.7 \\
\hline Nontreated & 483 & 28.9 & 73 & $1.5 \mathrm{ab}$ & 8.0 & 9 & 3.5 & 60 & 15.2 \\
\hline$P>\mathrm{F}$ Fungicides & & 0.7628 & & 0.0023 & 0.3473 & & 0.8506 & & 0.8769 \\
\hline
\end{tabular}


In conclusion, growers concerned with the environmental impact of copper and other inorganic fungicides should alternate with biorational products or extend their copper spray interval. They will likely achieve a similar level of downy mildew and powdery mildew disease management and marketable yield compared with weekly copper applications and, in some seasons, may also observe reductions in disease severity. However, the performance of biorational products is variable under open-field conditions and will not generally improve disease management compared with copper alone. Therefore, reliance on biorational products for downy mildew or powdery mildew disease management in organic vegetable production is not recommended at this time. Growers should be educated to the nuances and limitations of biorational products.

\section{Acknowledgments}

We thank D. Armentrout, K. Powell, A. Phillips, and M. Johnson for their assistance with this project. This work was partly supported by the United States Department of Agriculture's National Institute of Food and Agriculture (USDANIFA) through the Organic Transitions Program, grant 2014-51106-22090. The sponsor played no role in the study design and implementation. Any opinions, findings, and conclusions expressed in this material are those of the authors and do not necessarily reflect the views of the USDA-NIFA.

\section{Literature Cited}

Adrees, M., Ali, S., Rizwan, M., Ibrahim, M., Abbas, F., Farid, M., Zia-UrRehman, M., Irshad, M. K., and Bharwana, S. A. 2015. The effect of excess copper on growth and physiology of important food crops: A review. Environ. Sci. Pollut. Res. Int. 22:8148-8162.

Brent, K. J., and Hollomon, D. W. 2007. Fungicide resistance: The assessment of risk. Fungicide Resistance Action Committee Monograph, 2nd Ed. CropLife International, Brussels, Belgium.

Cantliffe, D. J., Shaw, N. L., and Stoffella, P. J. 2007. Current trends in cucurbit production in the U.S. Acta Hortic.: 473-478.

Chandler, D., Bailey, A. S., Tatchell, G. M., Davidson, G., Greaves, J., and Grant, W. P. 2011. The development, regulation and use of biopesticides for integrated pest management. Philos. Trans. R. Soc. Biol. Sci. 366:19871998.

Chu, G., Wakelin, S. A., Condron, L., and Stewart, A. 2010. Effect of soil copper on the response of soil fungal communities to the addition of plant residues. Pebobiologia 53:353-359.

Cohen, Y., Rubin, A. E., Galperin, M., Ploch, S., Runge, F., and Thines, M. 2014. Seed transmission of Pseudoperonospora cubensis. PLoS One 9: e109766.

Cohen, Y., Van den Langenberg, K. M., Wehner, T. C., Ojiambo, P. S., Hausbeck, M., Quesada-Ocampo, L. M., Lebeda, A., Sierotzki, H., and Gisi, U. 2015. Resurgence of Pseudoperonospora cubensis: The causal agent of cucurbit downy mildew. Phytopathology 105:998-1012.

Crespo-Herrera, L.A., and Ortiz, R. 2015. Plant breeding for organic agriculture: Something new? Agric. Food Security 4:25. Online publication. doi:10.1186/ s40066-015-0045-1.

Criswell, A. D., Call, A. D., and Wehner, T. C. 2010. Genetic control of downy mildew resistance in cucumber - A review. Pages 13-16. Cucurbit Genetics Cooperative Report 33-34. North Carolina State University, Raleigh, NC. Available at: http://cuke.hort.ncsu.edu/cgc/cgc3334/cgc3334-4.pdf

Estevez de Jensen, C. E., Percich, J. A., and Graham, P. H. 2002. Integrated management strategies of bean root rot with Bacillus subtilis and Rhizobium in Minnesota. Field Crops Res. 74:107-115.

Everts, K. L., and Newark, M. J. 2014a. Evaluation of organic fungicides for management of mildew diseases of cucurbits, 2013. Plant Dis. Manage. Rep. 8:V210. Online publication. doi:10.1094/PDMR08.

Everts, K. L., and Newark, M. J. 2014b. Evaluation of fungicides for management of mildew diseases in organic squash and pumpkin, 2013. Plant Dis. Manage. Rep. 8:V211. Online publication. doi:10.1094/PDMR08.

Gan-Mor, S., and Matthews, G. A. 2003. Recent developments in sprayers for application of biopesticides-An overview. Biosystems Eng. 84:119-125.

Gent, D. H., Schwartz, H. F., and Nissen, S. J. 2003. Effect of commercial adjuvants on vegetable crop fungicide coverage, absorption, and efficacy. Plant Dis. 87:591-597.

Gianessi, L., and Reigner, N. 2006. The importance of fungicides in U.S. crop production. Outlooks Pest Manage. 15:209-213. Online publication. doi: 10.1564/17oct06.

Gilardi, G., Baudino, M., Garibaldi, A., and Gullino, M. L. 2012. Efficacy of biocontrol agents and natural compounds against powdery mildew of zucchini. Phytoparasitica 40:147-155.

Grand, L. F. 1987. Teleomorph of Sphaerotheca fuliginea on cucurbits in North Carolina. Mycologia 79:484-486.

Janousek, C. N., Lorber, J. D., and Gubler, W. D. 2009. Combination and rotation of bacterial antagonists to control powdery mildew on pumpkin. J. Plant Dis. Protect. 116:260-262.
Keinath, A. P., Holmes, G. J., Everts, K. L., Egel, D. S., and Langston, D. B., Jr. 2007. Evaluation of combinations of chlorothalonil with azoxystrobin, harpin, and disease forecasting for control of downy mildew and gummy stem blight on melon. Crop Prot. 26:83-88

Komárek, M., and Chrastny, V. 2008. Contamination of vineyard soils with fungicide-derived copper. Pages 109-118 in:Soil Contamination Research Trends. J. B. Domínguez, ed. Nova Science Publishers, Hauppauge, New York.

Latin, R. X. 1993. Occurrence of cleistothecia of Sphaerotheca fuliginea on pumpkin in Indiana. Plant Dis. 77:647.

Lebeda, A., and Cohen, Y. 2011. Cucurbit downy mildew (Pseudoperonospora cubensis)—Biology, ecology, epidemiology, host-pathogen interaction and control. Eur. J. Plant Pathol. 129:157-192.

Lebeda, A., Krístková, E., Sedláková, B., McCreight, J. D., and Coffey, M. D. 2016. Cucurbit powdery mildews: Methodology for objective determination and denomination of races. Eur. J. Plant Pathol. 144:399-410.

Marrone, P. G. 2009. Barriers to adoption of biological control agents and biological pesticides. Pages 163-178 in: Integrated Pest Management: Concepts, Tactics, Strategies and Case Studies. E. B. Radcliffe, W. D. Hutchison, and R. E. Cancelado, eds. Cambridge University Press, Cambridge.

Matheron, M. E., and Porchas, M. 2013. Efficacy of fungicides and rotational programs for management of powdery mildew on cantaloupe. Plant Dis. 97: 196-200.

McGrath, M. T. 1991. Cleistothecia of the powdery mildew fungus Sphaerotheca fuliginea observed on pumpkin in New York. Plant Dis. 75:1075.

McGrath, M. T. 2001. Fungicide resistance in cucurbit powdery mildew: Experiences and challenges. Plant Dis. 85:236-245.

McGrath, M. T., and Shishkoff, N. 1999. Evaluation of biocompatible products for managing cucurbit powdery mildew. Crop Prot. 18:471-478.

McGrath, M. T., and Shishkoff, N. 2003. First report of the cucurbit powdery mildew fungus (Podosphaera xanthii) resistant to strobilurin fungicides in the United States. Plant Dis. 87:1007.

McGrath, M. T., Staniszewska, H., Shishkoff, N., and Casella, G. 1996 Distribution of mating types of Sphaerotheca fuliginea in the United States. Plant Dis. 80:1098-1102

McGrath, M. T., and Thomas, C. E. 1996. Powdery mildew. Pages 28-30 in: Compendium of Cucurbit Diseases. T. A. Zitter, D. L. Hopkins, and C. E. Thomas, eds. American Phytopathological Society, St. Paul, MN.

Nicot, P. C., Stewart, A., Bardin, M., and Elad, Y. 2016. Biological control and biopesticide suppression of Botrytis-incited diseases. Pages 165-187 in Botrytis-The fungus, the pathogen and its management in agricultural systems. S. Fillinger and Y. Elad, eds. Springer International, Basel.

Ojiambo, P. S., and Holmes, G. J. 2011. Spatiotemporal spread of cucurbit downy mildew in the eastern United States. Phytopathology 101:451-461.

Ojiambo, P. S., Paul, P. A., and Holmes, G. J. 2010. A quantitative review of fungicide efficacy for managing downy mildew in cucurbits. Phytopathology 100:1066-1076.

Partridge, D. E., Sutton, T. B., and Jordon, D. L. 2006. Effect of environmental factors and pesticides on mycoparasitism of Sclerotinia minor by Coniothyrium minitans. Plant Dis. 90:1407-1412.

Pérez-García, A., Romero, D., Fernández-Ortuño, D., López-Ruiz, F., de Vincente, A., and Torés, J. A. 2009. The powdery mildew fungus Podosphaera fusca (synonym Podosphaera xanthii), a constant threat to cucurbits. Mol. Plant Pathol. 10:153-160.

Poland, J. A., Balint-Kurti, P. J., Wisser, R. J., Pratt, R. C., and Nelson, R. J. 2009 Shades of gray: The world of quantitative disease resistance. Trends Plant Sci. 14:21-29.

Prokop, M., and Veverka, K. 2006. Influence of droplet spectra on the efficiency of contact fungicides and mixtures of contact and systemic fungicides. Plant Prot. Sci. 42:26-33.

Quesada-Ocampo, L. M., Granke, L. L., Olsen, J., Gutting, H. C., Runge, F., Thines, M., Lebeda, A., and Hausbeck, M. K. 2012. The genetic structure of Pseudoperonospora cubensis populations. Plant Dis. 96:1459-1470.

Reddy, P. P. 2016. Biological control of plant pathogens. Pages 61-69 in: Sustainable Crop Protection Under Protected Cultivation. Springer, Singapore.

Rideout, S. L., Waldenmaier, C. M., Custis, J. T., Jr., and Wimer, A. F. 2010 Comparison of organic fungicides for the management of downy mildew in pumpkin, 2009. Plant Dis. Manage. Rep. 4:V032. Online publication. doi: 10.1094/PDMR04.

Romero, D., de Vincente, A., Zeriouh, H., Cazorla, F. M., Fernández-Ortuño, D. Torés, J. A., and Pérez-García, A. 2007. Evaluation of biological control agents for managing cucurbit powdery mildew on greenhouse-grown melon. Plant Pathol. 56:976-986.

Sharma, R. R., Singh, D., and Singh, R. 2009. Biological control of postharvest diseases of fruits and vegetables by microbial antagonists: A review. Biol. Control 50:205-221.

Thakore, Y. 2006. The biopesticide market for global agricultural use. Industrial Biotechnol. 2:194-208.

Thomas, C. E. 1996. Downy mildew. Pages 25-27 in: Compendium of Cucurbit Diseases. T. A. Zitter, D. L. Hopkins, and C. E. Thomas, eds. American Phytopathological Society, St. Paul, MN.

Thomas, C. E., Inaba, T., and Cohen, Y. 1987. Physiological specialization in Pseudoperonospora cubensis. Phytopathology 77:1621-1624. 
United States Department of Agriculture. 2014. Census of agriculture, 2012: Maryland state and county data. Report AC-12-A-20. United States Department of Agriculture, Washington, D.C. Available at: http://www.agcensus.usda.gov/ Publications/2012/Full_Report/Volume_1,_Chapter_1_State_Level/Maryland/mdv1. pdf

United States Department of Agriculture. 2015. Census of agriculture, 2014: Organic survey. Report AC-12-SS-4. United States Department of Agriculture, Washington, D.C. Available at: http://www.agcensus.usda.gov/Publications/ 2012/Online_Resources/Organics/ORGANICS.pdf

Lammerts van Bueren, E. T. L., Jones, S. S., Tamm, L., Murphy, K. M., Myers, J. R., Leifert, C., and Messmer, M. M. 2011. The need to breed crop varieties suitable for organic farming, using wheat, tomato and broccoli as examples: A review. NJAS Wagening. J. Life Sci. 58:193-205.

van den Bosch, F., Paveley, N., Fraaije, B., van den Berg, F., and Oliver, R. 2015. Evidence-based resistance management: A review of existing evidence. Pages
63-76 in: Fungicide Resistance in Plant Pathogens. H. Ishii and D. W. Hollomon, eds. Springer, Tokyo.

Van-Zwieten, L., Merrington, G., and Van-Zwieten, M. 2004. Review of impacts on soil biota caused by copper residues from fungicide application. Proceedings of the $3^{\text {rd }}$ Australian New Zealand Soils Conference. 5-9 December 2004, University of Sydney, Australia.

Wszelaki, A. L. and Miller, S. A. 2005. Determining the efficacy of disease management products in organically-produced tomatoes. Plant Health Prog. Online publication. doi:10.1094/PHP-2005-0713-01-RS.

Zhang, S., Vallad, G. E., White, T. L., and Huang, C.-H. 2011. Evaluation of microbial products for management of powdery mildew on summer squash and cantaloupe in Florida. Plant Dis. 95:461-468.

Zhu, S. S., Liu, X. L., Wang, Y., Wu, X. H., Liu, P. F., Li, J. Q., Yuan, S. K., and Si, N. G. 2007. Resistance of Pseudoperonospora cubensis to flumorph on cucumber in plastic houses. Plant Pathol. 56:967-975. 